\title{
Mi padre moro, yo moro: The Inheritance of Belief in Early Modern Iberia ${ }^{1}$
}

\author{
Mercedes García-Arenal
}

The period of the late sixteenth and early seventeenth centuries was a time of crisis and paradigm shift in wide-ranging areas of cultural, intellectual and spiritual life throughout Europe, as a long century of religious strife ended in a stalemate between Catholics and Lutherans, but also with the consolidation of numerous sects among the followers of the Sola scriptura. ${ }^{2}$ By the mid-sixteenth century, the fiercest moments of the struggle between Lutheran reformers and orthodox Catholics had passed. Luther had blazed a trail in his criticism of the Church's authority and once that authority had been challenged, a need arose to seek out a criterion for truth. ${ }^{3}$

This crisis also affected Spain, and its manifestations were juxtaposed alongside the long-running problem caused by the mass conversions of Jews and Muslims in the early sixteenth century and by the continued existence of significant, identifiable groups of Converso origin. These groups of 'new converts' meant that Iberian Catholics became 'Old Christians'. As a result, Iberia was to witness phenomena of great interest such as reactions of a relativist, comparativist or even skeptical nature, inextricably linked to dissimulation and doubt. ${ }^{4}$

1 The research leading to these results has received funding from the European Research Council under the European Union's Seventh Framework Programme (FP7/2007-2013) / ERC Grant Agreement number 323316, CORPI project 'Conversion, Overlapping Religiosities, Polemics, Interaction. Early Modern Iberia and Beyond'. This contribution was translated into English by Martin Beagles. Special thanks are due to Miriam Bodian and to James Amelang for reading and offering insightful comments on an earlier draft of this essay.

2 Among a wide secondary bibliography, see as an overview Benjamin J. Kaplan, Divided by Faith: Religious Conflict and the Practice of Toleration in Early Modern Europe (Cambridge: Harvard University Press, 2007).

3 Richard Popkin, The History of Scepticism: From Erasmus to Spinoza (Berkeley: University of California Press, 1979), p. 41.

4 I would like to refer the reader to two texts which were fundamental in the creation of this paper and which will be frequently cited throughout it: Jeremy Robbins, Arts of Perception: The Epistemological Mentality of the Spanish Baroque, 1580-1720 (London: Routledge, 2007), and Michele Olivari, Avisos, pasquines y rumores. Los comienzos de la opinión pública en la España del siglo XVII (Madrid: Cátedra, 2014).

(C) MERCEDES GARCÍA-ARENAL, 2016 | DOI 10.1163/9789004324329_013

This is an open access chapter distributed under the terms of the CC-BY-NC-ND License. 
There is wide and varied evidence that coerced conversion on a massive scale produced a lessening of faith within part of the converted groups, and that the systematic evangelization campaign of the early sixteenth century sowed doubts even in the minds of some Old Christians. ${ }^{5}$ Conversion, in short, eroded belief, as this paper will try to show. The difficulty lies in assessing the influence of conversion on religious dissidence and establishing how such dissidence came to be categorized as heresy, and frequently identified with converts from Islam and Judaism. The main aim of this paper is to reflect on how Spanish ecclesiastical authorities, and especially the Inquisition, worked on a definition of heresy and heterodoxy by categorizing a series of commonly held propositions (proposiciones, statements or pronunciations considered as deviant by the Inquisition), placing particular stress on those statements which postulated that 'each is saved in his own law', or that 'we believe by inheritance and in accordance with the religion of our parents', or that 'belief may legitimately be dissimulated when the believer is subjected to violence'. All in all these propositions suggested acceptance of the idea that one believes by 'inheritance', and that any transference of allegiance from one religion to another is necessarily doomed.

In the late sixteenth and early seventeenth centuries, statements of this kind were repeatedly attributed to converts of Muslim origin, known as Moriscos, and this led to many Christians regarding such ideas as typical Islamic beliefs. Propositions showing various kinds of religious dissidence, which were widespread throughout Spanish (and European) society, became identified with Islam and with the practice of Islam, as will be shown in these pages.

Some of the attitudes and manifestations to be considered in this essay were also related to a widespread feeling of deep pessimism. Recent historiography has established a link between that feeling of pessimism and a skeptical attitude. The rise of interest in Skepticism that occurred in late sixteenth-century Spain compelled Spaniards to confront the moral and political consequences of human ignorance and a world-view premised on the omnipresence of deceit and the treacherous relationship between appearance and reality. Jeremy Robbins has vividly described the main features of a mentality steeped in epistemological (and thence moral) pessimism, largely fostered by the sustained creative interaction of the Skepticism and Stoicism that were so characteristic of seventeenth-century Spain. This interaction forged a distinctive view of the

5 John Edwards, 'Religious Faith and Doubt in Late Medieval Spain: Soria circa 1450-1500', in Religion and Society in Spain, c.1492 (Aldershot: Ashgate, 1996). 
nature and extent of human knowledge and had a decisive influence on questions of agency, morality, reason of state, trust and honor. ${ }^{6}$

It is clear that the inability to know, based on ignorance, repression and perplexity, is not the same as philosophical inability to know, but I want to suggest that both could overlap and have wide political and social implications. Epistemological and moral pessimism for example, was closely related to the specific hopelessness caused by the failure of the Spanish church's pastoral strategies, particularly as far as the Moriscos were concerned. ${ }^{7}$ Many of the clergy believed that this failure had occurred as a result of the lack of proper attempts to persuade new converts, rather than because of an unshakeable clandestine Islamic religion. In other clergymen, reactions to a realization of failure gave rise to attempts to mitigate their own responsibility by claiming, for instance, that evangelization had been impossible because in groups such as the Moriscos, belief was inherited, or that Jews could not be converted. ${ }^{8}$ The Muslims held, they claimed, that one must always follow the faith of one's parents. As one frustrated missionary wrote, 'Terrible are the mute and silent arguments that make the blood cry out within their veins. After we preach to them, these wretches respond my father Moor, Moor myself '. 9

The practical impossibility of spreading the gospel among the Muslims was also explained by reference to the idea that Muslims thought dissimulation was legitimate, meaning that a genuine assessment of their real beliefs could never be made, their heart of hearts never be pierced. Such claims, which lie at the core of this essay, occasionally led commentators to go so far as to express doubts about the transformational capacity of baptism. The claim that belief was inherited ultimately resulted in an identification between cultural or religious characteristics and physical inheritance.

The failure, therefore, was not only about evangelization, but also about identifying sincere belief. The failure or uncertain success of the Inquisition itself in controlling other faiths meant that orthodoxy became identified with

6 This is the general argument of Robbins, Arts of Perception, especially chapters 1-2.

7 Rafael Benítez Sánchez-Blanco, Heroicas decisiones. La monarquía católica y los moriscos valencianos, (Valencia: Institució Alfons el Magnànim, Diputació, 2001), and 'The Religious Debate in Spain', in The Expulsion of the Moriscos from Spain: A Mediterranean Diaspora, (ed.) M. García-Arenal and G.A. Wiegers, (Leiden: Brill, 2014), pp. 102-31.

8 Miriam Bodian, 'Behind Closed Doors: A Dominican Friar's Debate with a Dutch Jew, from the Records of an Inquisition Trial, Lisbon 1645-1647', Jewish Studies Quaterly, 21 (2014): pp. 36290, esp. p. 382 .

9 Antonio Domínguez Ortiz, 'Notas para una sociología de los moriscos españoles', Miscelánea de Estudios Árabes y Hebraicos, 11 (1962): pp. 39-54. 
genealogy. ${ }^{10}$ And so we will see throughout this paper the enormous theological and doctrinal contradiction that led Iberian Church authorities from a messianic, Pauline hope of universal conversion, to the creation of what I will call the Spain of blood and milk.

\section{The Jesuit Pedro de León on How to Convert the Moors: the Three Major Obstacles}

I would like to begin by taking as the central axis of the first part of this essay the text written by the Jesuit Pedro de León $\left(1545^{-1632)}\right.$ a few years after the Expulsion of the Moriscos (1609-14). In 1616 León finished his Compendio de algunas experiencias en los ministerios de que usa la Compañía de Jesús con que prácticamente se muestra con algunos acaecimientos y documentos, of which only the first volume has ever been published. ${ }^{11}$ The third volume of this work includes the chapter: Trátase de cómo se an de convertir los Moros y Moriscos provándoles que van errados en seguir la seta de Mahoma (On how to convert the Moors and Moriscos by proving to them that they err in following the sect of Muhammad)..$^{12}$ According to remarks in the text itself, the Jesuit composed it immediately after the Expulsion. However, it is in fact the summary of a much longer text probably conceived when the presence of Moriscos on the Iberian Peninsula still made their evangelization at least a theoretical possibility.

Pedro de León is a well-known figure, though not for this part of his religious and intellectual activity. He is more renowned for his participation in popular missions in Spain and his work with prison inmates and prostitutes in Seville. ${ }^{13}$ In his youth he had lived in Granada and it was in this city that he had, in the 1570s, become a disciple of the famous Morisco Jesuit Juan de Albotodo, defined by León as an honor to the Company 'because despite his Morisco

10 David Nirenberg's excellent article is required reading on this subject: 'Mass Conversion and Genealogical Mentalities: Jews and Christians in Fifteenth-century Spain', Past and Present, 174 (2002): pp. 2-41.

Partially edited and studied in Pedro de León, Grandeza y miseria en Andalucía. Testimonio de una encrucijada histórica (1578-1616), (ed.) Pedro Herrera Puga (Granada: Facultad de Teología, 1981).

Vol. 3, fol. 201ff of the manuscript of the Biblioteca Universitaria de Salamanca ms. 579 . I am grateful to Michele Olivari for pointing out to me the existence of this unpublished manuscript. Stefania Pastore provided me with photocopies of the copy kept at the Biblioteca Universitaria de Granada.

13 Antonio Domínguez Ortiz, 'Vida y obra del P. Pedro de León', Archivo Hispalense, 83 (1957): pp. 157-96. For a subtle reading, see Olivari, Avisos, pasquines, p. $368 f f$. 
caste, he was a rose among thorns.'14 León had first-hand experience of the perils represented by these thorns, for he was present in the valleys of the kingdom of Granada during the well known and fierce revolt known as the Alpujarras War (1568-70). In order to analyze his text of 1616 , it is necessary first to consider the connection between the different kinds of missionary work León carried out during his life. Michele Olivari has claimed that it was this work that led León to undertake his analysis of the attitudes and moral behavior of the Moriscos, in preparation for a catechizing mission which he never undertook or which may have been interrupted by the Expulsion of 1609-14. ${ }^{15}$ But although León may have had the opportunity to participate in pastoral work among the Moriscos at the time of his presence in Granada during key periods of the Morisco problem, the fact is that he never did so. León's missions took place in the mountains of Granada between 1590 and 1591, several years after the Granadan Moriscos had been expelled to Castile. He focused his attention on the mainly Galician populations sent to re-populate the region and whom he found (or so he claimed) to be worse in many ways than the Muslims who had preceded them. León used the Granadan Muslims as a point of comparison and a model of industry, austerity and piety towards their own people, especially widows and orphans; he also portrayed them as having been so honest that they never stole from a neighbor and never got drunk. ${ }^{16}$ The populations León found most difficult in his pastoral work, those he found most resistant when it came to receiving any kind of religious message, were, in his own words, the men who worked in the tobacco industry and those who worked as tuna fishermen in the almadrabas (fisheries) of the Duke of Medina Sidonia. León regarded these men as worse than Muslims, arguing that at least the latter believed in God. León's thoughts on this subject may therefore not have been intended to express appreciation of the Moriscos so much as to show the populations who were the object of his mission how they ought and ought not to behave, and how their behavior placed them at a extremely low level on the human scale, lower even than that of the Moors. This was probably also the reason for other literature on the supposed indoctrination of Muslims,

León, Grandeza y miseria, p. 198, apud Olivari, Avisos, pasquines, p. 370. On Father Juan de Albotodo and other Morisco Jesuits see Francisco de Borja Medina, 'La Compañía de Jesús y la minoría morisca (1545-1614)', Archivum Historicum Societatis Iesu, 57 (1988): pp. 4-137. For the most famous of them all, Ignacio de las Casas, see Youssef El Alaoui, Jésuites, Morisques et Indiens. Étude comparative des méthodes d'évangélisation de la Compagnie de Jésus d'après les traités de José de Acosta (1588) et d'Ignacio de las Casas (16051607) (Paris: Honoré Champion, 2006), p. 574.

15 Olivari, Avisos, pasquines, p. 368.

16 León, Grandeza y miseria, pp. 104-08. 
as occurred in other seventeenth-century Jesuit treatises of polemics against Islam: ${ }^{17}$ the aim was to teach and revive the Catholicism of the peoples among whom he carried out his missionary work rather than to polemicize with the scarce number of Muslims still living in the Peninsula. ${ }^{18}$

This does not mean that León did not know what he was talking about when he discussed the Moriscos. He felt a hostility towards them that was occasionally tempered by piety and sympathy. He was also filled with piety and sympathy in his dealings with his flock of convicts and prisoners, and the sincerity of his feelings led many such individuals to listen to him and become reconciled to the faith. ${ }^{19}$ León begins his text by pleading for compassion for the Moriscos, both for their souls and their bodies. Such compassion was intended to be a way of bringing about their conversion.

Regardless of whether León had a relatively moderate attitude towards the Moriscos, the aspect of his text which is of greatest interest here is the way in which he uses it to diagnose and tease out three major obstacles to the conversion of the Muslims. The first and main difficulty is that the Moriscos 'cling to their sect (although they do not understand it) because their parents followed it: my father was a Moor and I am a Moor.20 León claims that the Moriscos largely lacked knowledge of Islam (both in dogma and in law) and did not understand it. They were also ignorant of the tenets of Catholicism. They lived without a law, and he wrote that 'when we want to say that someone lives at their whim, or at their own free will, we say that he is like a Moor without law',21

Especially the still unpublished treatise by the Jesuit Juan de Almarza, who in the midseventeenth century wrote his Catecismo de moros, Real Academia de la Historia [RAH], ms. 9-2263. Another Jesuit, Francisco Alemán, rector of the Jesuit College from 1625 to 1627 was the author of an Explicación de la doctrina cristiana para los moriscos de Granada con la refutación de sus principales errores. See Bernard Vincent, El río morisco (Valencia: Universitat de Valencia, 2006), p. 77.

Such is the conclusion of Emanuele Colombo on the work of the Jesuit Tirso González de Santalla, Convertire i musulmani. L'esperienza di un gesuita spagnolo del Seicento (Milan: Mondadori, 2007).

19 'Debemos tener compasión por sus cuerpos, tan castigados, penitenciados, encarcelados, amedrentados y desterrados, y assí con una misma medicina se curarán las llagas de sus almas y de sus cuerpos' (We should have compassion for their bodies, which are so sorely punished, with penances imposed upon them, imprisoned, intimidated and banished, and with the same medicine will be cured the wounds of their souls and their bodies); León, Compendio, fol. $201 r$. padre moro y yo moro'; León, Compendio, fol. 201r. 
in a very expressive identification of disbelief, heresy and Islam. This is also a highly significant association with Islam of belief in the lack of importance of one's own law, or in any case, ignorance of Islam. Though I will not be dealing with converts from Judaism in this essay, it is important to point out that exactly the same accusation of ignorance of their own law and religion was addressed at them as well. ${ }^{22}$ I will return to this issue further on.

León was not the only anti-Islamic polemical author to express such ideas; other authors, like Bernardo Pérez de Chinchón in his Antialcorano, wrote in similar terms. ${ }^{23}$ Such authors insisted that the Moriscos did not know their own religion. ${ }^{24}$ León argues in a fictitious dialogue with a Muslim that it is not a good thing to follow one's parents if they are in error, as are the Gentiles or the Jews, but to use reason. ${ }^{25}$ To this the Muslim says that Christians also follow the faith of their parents, but León argues that they are not Christians because their parents were, but because they follow 'truth', 'the true law'. ${ }^{26}$ León devotes a long passage of development to this point, no doubt with the intention of arousing horror in the reader or listener with the examples he offers of awful things that parents can do: to what extent are we to follow our parents' beliefs and behavior? It is at this point that he discusses parents who kill their children, fathers who practice sodomy and so on. Unlike the Muslims, León says, Christians are not Christians out of love for their parents but out of love of God. This is a highly important claim: Muslims are said to love their parents above and beyond their love or search for God. But Muslims also cling to the tradition of their parents because this is the way in which they reach certainty about what must be considered the true law. If their ancestors 'were

See as an example Bruno Feitler, The Imaginary Synagogue: Anti-Jewish Literature in the Portuguese Early Modern World (16th-18th Centuries) (Leiden: Brill, 2015), pp. 89-91.

23 Bernardo Pérez de Chinchón, Libro llamado Antialcorano, que quiere dezir contra el alcoran de mahoma (Valencia: Juan Jofré, 1532) [edited as Antialcorano. Diálogos cristianos. Conversión y evangelización de Moriscos, by Francisco Pons Fuster (Alicante: Universidad de Alicante, 2000)].

24 'Todos por la mayor parte sois gente que ni sabeys leer ni escrevir: ni sabeys nada de dios ni del cielo, ni de la tierra: sino andar por los campos como salvages a la manera que andan los alarabes en bervería'; Pérez de Chinchón, Antialcorano, pp. 41-42 (fols. clxviii, bis v-clxi).

25 'Si el padre es ciego, no por eso el hijo se saca los ojos' (If the father is blind, this does not mean that the child has to pull out his own eyes). León, Compendio, fol. 202v.

$26 \quad$ 'Y si nos dijesen los moros y los gentiles y vosotros los christianos, ¿no seguís tambien la ley de vuestros Padres? Debemos responderles que seguimos su fe y ley [note the use here of the two terms $f e$ and ley] pero no la seguimos porque ellos la siguieron sino porque sabemos que es la verdadera en que nos havemos de salvar'; León, Compendio, fol. 202v. 
condemned', they should not be so stupid as to condemn themselves also, says León. And herein lies the second and related difficulty, that of their belief, which according to León is also their response to León's arguments about the nature of the true law in which to attain salvation: their dictum que cada uno se salva en su ley (each is saved in his own law).

The third obstacle to the effective conversion of Muslims was the issue of their dissimulation of belief. They were unaware of many aspects of their own law and did not practice others out of fear of Christians, but they clung to their desire to be Muslims over and above these circumstances, 'and since the law of Muhammad says that even if they say otherwise in public, this will be enough for them to be saved'. León continues: 'For they hold that in cases of coercion they may act in this way, holding in their hearts that they are Moors (though they say otherwise with their mouths), and that this will be enough for them to be saved. ${ }^{27}$ The Muslims lived without a law because they did not know their own law but were permitted by Muhammad to dissimulate, to have one faith in their hearts and practice the regulations and rituals of Catholicism in order to keep up appearances without losing their status as Muslims. They were, in other words, without law. Yalgunos de los moros dicen que cada uno se salva en su ley (And some Muslims say that each is saved in his own law). ${ }^{28}$

Ignorance of their own law and, above all, the practice of dissimulation, made it virtually impossible to know anything about the internal beliefs of the Moriscos. This was also the conclusion of a Memorial written to Felipe III in 1608, shortly before the Expulsion: 'No hope is or can be had, judging morally and in accordance with Christian prudence, that they will persevere in any faith other that the one they have now, or that they will want to know anything of ours; and if they do know of it, it will be in order not to believe it'. ${ }^{29}$ Even more pessimistic was the position on the possibility of conversion held by Fray Francisco de Ribas of the Order of the Minims, who thought it was futile even to attempt to convert Muslims: 'With there being so little hope of their conver-

27 'y que la ley de Mahoma permite que aunque digan otra cosa de fuera bastará para salvarse (...) Pues tienen para sí que en caso de violencia pueden, teniendo en el corazón que son moros (aunque digan otra cosa con la boca) y que esto bastará para salvarse'; León, Compendio, fol. 203v.

28 León, Compendio, fol. 203r.

29 'Ninguna sperança se tiene ni puede tener, juzgando moralmente y según prudencia christiana, de que perseverarán en otra fe que agora tienen, ni de que querrán saber de la nuestra, y que en caso que la sepan será para no creerla'; Antonio Mestre, 'Un documento desconocido del Patriarca Ribera escrito en los momentos decisivos sobre la expulsión de los moriscos', in Estudios dedicados a Juan Peset Aleixandre, (Valencia: Universitat de Valencia, 1982), pp. 737-39; cited in Benítez, 'The Religious Debate', pp. 106-07. 
sion, to insist that they do so is nothing more than to give them reasons for belittling us, for in the end we allow them to live in their religion knowing that we know they are Moors.' ${ }^{30}$

The idea that the Moriscos lacked both knowledge and belief, and that their own inability to know obliged them to cling to the religion of their fathers is, in my view, a fundamentally skeptical position in the minds of the inquisitors. León's text also contains skepticism and doubt, as it often expresses the difficulty of ascertaining what it is that the Moriscos think or believe, which leads him to doubt the ability of the Inquisition to make judgments in matters of belief. One very explicit example can be found in his story of a young Morisco girl who was handed over by the Inquisition to the secular arm of the law to be executed. The prisoner had been accused of crypto-Muslim practices by her own relatives and other Morisco neighbors. But it was thought that it was the very sincerity of her Christian beliefs which had led to the accusations and to false evidence being given against her. León admits that the judges sentenced her secundum allegata et probata, but his final comment is a manifestation of skepticism: 'God knows what this is all about'. ${ }^{31}$

\section{Each Follows the Religion of his Parents, Each is Saved in his Own Law}

León was not the only author to categorize the same three obstacles to the conversion of the Moriscos. They can be found over and again in many different types of sources.

Inquisition records contain frequent mentions of the belief discussed by Pedro de León that 'each is saved in his own law', a crime codified and expressly persecuted by the Inquisition. ${ }^{32}$ For many of those who were tried for saying 'each is saved in his own law', this belief had brought the comforting thought that parents and grandparents who had died before the publication of the decrees enforcing conversion might still be saved. It was also a statement against the imposition of one sole truth, and it contains a dose of relativism

30 'Haviendo tan poca esperança de que se conviertan el porfiar que lo hagan no es más que darles materia para que nos tengan en poco, pues al cabo los dexamos vivir en su secta sabiendo ellos que nosotros sabemos que son moros'; Benítez, 'The Religious Debate', p. 107 .

$31 \quad$ 'Dios sabe lo que hay en esto'; León, Grandeza y miseria, p. 485.

$3^{2}$ Stuart B. Schwartz, All Can Be Saved:Religious Tolerance and Salvation in the Iberian Atlantic World (New Haven: Yale University Press, 2008). 
and detachment from established religion. It had an impact on the very concept of religion because of the skepticism it entails.

The dictum 'each is saved in his own law' also shows the degree to which early modern Spain was a polemical arena. Anti-Muslim polemicists held that belief in this dictum was one of the major errors of Islam. Indeed, the already quoted preacher Bernardo Pérez de Chinchón, in his Antialcorano, published in 1535, notes that 'some of the learned men among the Muslims say that each is saved in his own law: the Jew in his, the Christian in his, the Muslim in his'. It was singularly present in the work of other seventeenth-century Jesuits who wrote on how to convert Muslims. Such was the case of Tirso González de Santalla, who criticized the statement in the Qur'an that each could be saved in his own religion, Jews within Judaism, Christians in Christianity and Muslims in Islam. ${ }^{33}$ In the climate of enthusiasm over the victory of the Holy League at the Battle of Vienna (1683) which halted the advance of the Ottoman Empire, González de Santalla, a professor at the University of Salamanca and future Superior General of the Company of Jesus, published his Manuductio ad conuersionem mahumetanorum (Madrid, 1687) ${ }^{34}$ This book was very widely read. González de Santalla poured into this manual an account of his experiences as a preacher, apologist against Islam and ardent missionary. Like Pedro de León, he had spent most of his life crisscrossing Spain as a preacher in popular missions and in order to catechize and instruct Christians. González Santalla had devoted huge efforts to the composition of lengthy sermons for the benefit of the very small numbers of Muslims (generally captives or the slaves of noble families) still to be found in the towns and cities of Andalusia, and had orchestrated the public staging of their conversion to Catholicism.

Manuel Sanz, a Spanish Jesuit and calificador of the Inquisition of Malta, ${ }^{35}$ insisted that González had converted Muslims and disavowed them of their belief that each is saved in his own law. The target of Sanz's diatribe seems to have been the same as in the case of González Santalla, namely Lutheran and Calvinist beliefs, rather than Islam itself, which is likely to have been a just a pretext. Gaspar de Escolano, in his Memorial of 1600 on the history of Valencia, drew up a list of 'Muhammedan errors', amongst which he highlights that of believing that although our law is good and holy, so is theirs and that of the

33 Colombo, Convertire imusulmani, p. 47.

34 Elías Reyero, Misiones del Padre Tirso González de Santalla, XIII prepósito general de la Compañía de Jesús (1665-1686) (Santiago: Editorial Compostelana, 1913).

Manuel Sanz, Breve trattato nel quale con ragioni dimostrative si convincono manifestamente i Turchi esser falsa la legge di Maometto e vera solamente quella di Cristo (Catania, 1691; Seville, 1693). 
Jews, and that all are saved who keep to them', and then insisted that one of the Moriscos' clear errors was the belief that each is saved in his own law (creer que cada uno se salva en su ley). ${ }^{36}$ By contrast, Juan de Almarza, also a Jesuit and author of a Catecismo de moros, specified that there were two classes of Muhammedans, those who believe that each is saved in his own law and others who say that none can be saved unless it is within the law of Muhammad'. ${ }^{37}$ This is a very important statement because it discriminates between different kinds of Muslims and does not identify the belief in each being saved in its own law with the tenets of Islam. In fact, Almarza draws a more complex picture than most of other writers on the conversion of the Muslims. Almarza had previously explained that there were four laws, those of the Christians, Moors, Jews and Gentiles or pagans. And he added: 'There are no other laws than these. There is no law of Atheists, because there is no nation which follows this error. Atheists are found in all of the laws, because there is no shortage of evil people in any one of them, though more in some than in others, and such people say that there is no God, and no life beyond this present one'. There were those, then, who believed there was no God, and that one is only born and then dies. ${ }^{38}$ Let us take this as 'atheism.' ${ }^{39}$

Is Almarza associating the quasi-agnosticism that can be an ingredient of 'each is saved in his own law' with atheism? The quotation sheds interesting and revealing light on the state of affairs in seventeenth-century Iberia: according to Almarza, atheists could be found in any of the religious communities. More revealingly, Fray Jerónimo Gracián de la Madre de Dios, writing in 1611, classified seven kinds of atheists. ${ }^{40}$ This included a group who live without faith or law, desiring to be externally and internally free and to live at their own free will. Others rejected all forms of law. The freedom to follow the law or not is what was adopted by the Marabouts of Barbary, for example the masters of

36 Rodrigo de Zayas, Los moriscos y el racismo de estado. Creación, persecución y deportación (1499-1612) (Cordoba: Almuzara, 2006), doc. XLII, p. 478, p. 485.

37 Almarza, Catecismo de moros, fol. 6iv.

38 This was another proposition persecuted by the Inquisition. See Francisco Márquez Villanueva, 'Nasçer e morir como bestias (criptoaveroísmo y criptojudaísmo)', in De la España judeoconversa. Doce estudios (Barcelona: Edicions Bellaterra, 2006), pp. 203-27.

39 'No hay ley de Ateistas porque no ay nación que siga este error. Los Ateistas se hayan en todas las leyes, porque en qualquiera dellas no faltan algunos desalmados, en una más y en otra menos, que dicen que no ay dios ni más vida que esta presente'; Almarza, Catecismo de moros, fol. 13r.

40 Fray Jerónimo Gracián de la Madre de Dios, Diez lamentaciones del miserable estado de los atheistas de nuestros tiempos (Brussels: Rutger Velpius and Huberto Antonio, 1611), pp. 12-24. 
the Suf brotherhoods who had given themselves up to ascetic practices to such an extent that beyond a certain level they became free of all law. ${ }^{41}$ Gracián ends by explaining that the Muslims and the Jews, as well the heretics of his day, which is to say the Lutherans (all three religions were in his view mixed up with atheism), tended towards atheism when they realized that theirs was not the true sect, instead of turning to and joining the Catholic fold. Evangelization and polemics could therefore convince them that their original religion was false, but not that Catholicism contains the truth. According to Gracián converts can even become proper, full-blooded atheists. Cervantes wrote the words fino ateista te muestras (a fine atheist you show yourself to be) in describing ironically a character in La gran sultana who is a renegade and who directly admits yo ninguna cosa creo (I do not believe in anything). ${ }^{42}$ This was the case, according to Gracián, of 'the Jews who live in Amsterdam, where they have built them a synagogue, for most of them are atheists even though they follow the external rites of Judaism.43 ${ }^{43}$ Other contemporary Portuguese sources address this question of atheism in regard to descendants of converts from Judaism, linking, as Gracián does, atheism to the Judaizers' indecision in matters of religion and to their ignorance of both laws. Valerio de San Raimundo tells converts from Judaism 'you are neither Christians nor Jews. You can be called atheists' and his contemporary Estêvão de Santana: 'You live like Atheists, without God, without Law ... Receiving the Sacraments in the Church and practicing yours in the Synagogue! This is not being a Christian or a Jew or

'La segunda libertad es la de las leyes, y por exemplo della dirè lo que oy día passa en los Marabutos de Berbería. Tuvieron estos principio de dos hijos de Haly, sobrino y succesor de Mahoma, que se dieron en cierto tiempo a increýbles abstinencias y asperezas de cuerpo; y viniendo un día ante su Padre disfigurados, flacos y en los huessos, dixoles el Padre, que (según la ley de Mahoma su tío), ya estavan libres de todas las leyes, y podían cessar de hazer penitencia y cualquiera cossa que hiziessen de allí adelante, sería santa y perfeta. Hallóse presente un moro llamado Marabutin, y escrivió un libro de la secta de los Marabutos, en que dize, que llegando una persona a cierto grado de perfición (que ellos imaginan se alcança con sus asperezas), está libre de toda la ley, y cualquiera cosa que hiziere, será santa. Y assí me contó quien lo vio por sus ojos, que llegando un Marabuto dessta secta carnalmente, en vna calle publica, delante de todo el mundo a una borrica, acudieron muchos moros a tomar pelos della, para reliquias, como sanctificada por su Marabuto'; Gracián, Diez lamentaciones, pp. 58-6o. In Spain the late Alumbrados, such as those of Extremadura in the 1570 s thought that the act of confession could be dismissed, even before taking communion, if one's soul had already attained a certain level of perfection, at which point they could no longer sin and therefore had no need for confession. Francisco Márquez Villanueva, Moros, moriscos y turcos en Cervantes. Ensayos críticos (Barcelona: Bellaterra, 2010), p. 157.

Gracián, Diez lamentaciones, pp. 278-79. 
a believer or a Catholic. So what is it? It is to be phantasms of religion, chimeras of faith, atheists of all laws because you are heretics of one and the other, hobbling in both' ${ }^{4}$

Fray Gerónimo Gracián's text neatly expresses two of the main underlying ideas of this paper. Firstly, there is the tendency to cluster together all heterodox trends and to attribute them to Moors and Jews. Secondly, there is the notion that conversion from other religions frequently leads to a degree of lack of belief or disengagement from religion, described by Gracián and others as 'atheism'.

\section{Muslims can Pretend to Believe a Law Other than the One in their Hearts}

The notion of legitimate dissimulation was nevertheless seen as the main obstacle, and the one which obsessed preachers and authors of treatises on Muslims. Almarza, whose text often resembles that of León, also makes reference to the idea of permitted dissimulation:

Muhammad teaches in his Koran ... that a Muhammedan can for fear of some evil outwardly pretend to believe a law other than that in his heart: so that if he is afraid that some harm will come to him by saying that he is a Muslim he may say that he is not: and he can for the same reason be baptized, and confess, though in being baptized and confessing he has others believe he is a Christian and not a Muslim. The reason given is that God is only worshipped from the heart and if they have the law of Muhammad in their heart it does not matter if they deny it with their mouths, or by their actions, if by confessing this they bring some harm upon themselves: thus they do not sin if they deny it outwardly but confess within. ${ }^{45}$

Another example is Fray Marcos de Guadalajara, a staunch apologist for the Expulsion of the Moriscos, who also insisted on two determining character-

44 'Viveis como Atheistas, sem Deos e sem ley... Receber os Sacramentos da Igreja e praticar os vossos na Sinagoga! Isto nem e ser Christao nem Judeo, nem fiel, nem Catholico. Pois que he? He de ser fantasmas da religiao, quimèras da fé, Atheistas de todas as leys; porque hereges de huma, e outra, claudicais en ambas'. Quoted by Bruno Feitler, The Imaginary Synagogue, pp. 90-91

Almarza, Catecismo de moros, fol. 156r-v. 
istics of Morisco belief or disbelief. Guadalajara wrote that the Moriscos 'punctiliously obeyed the precepts of the Qur'ān, and did what the Church commanded (if they could not avoid it), protesting within themselves that they were forced to do so. They held as true that each of us could be saved in his Christian, Jewish or Moorish law, holding faithfully to it: which is why St Vincent Ferrer converted so few of them'. ${ }^{46}$ Also: 'With the permission and license granted them by their damned sect, they were able to dissemble outwardly on forced occasions, without sinning, any religion with such insistence that they conserved their heart for their false, swindling Prophet; we saw so many of them die adoring the Cross and speaking with approval of Our Catholic Religion at the same time that they were inwardly true Muhammedans'. ${ }^{47}$

The late sixteenth century witnessed the spread of this belief that Moriscos deemed it legitimate to dissimulate in order not to lose their status and identity as Muslims. In 1587 the Bishop of Segorbe wrote to Felipe II to explain to the king some of the problems he had encountered during his preaching campaigns:

It is a certain and plain fact that all the Moors in Spain, and outside it, by tradition from some to others and through doctrine and the teachings of their alfaquis and masters, believe as a point of faith that if to excuse some violence or from fear of some punishment they receive Christian baptism or confess to Jesus Christ or perform any other Christian duty, they do not offend Muhammad if in their hearts they believe, love and adore him ... and that to pray in accordance with both rites does not violate the sect of Muhammad if they hold it dearly in their hearts and perform some of its ceremonies secretly, out of fear of some violence or

46 'Obedecían con puntualidad los preceptos del Alcorán, hazían lo que la Iglesia mandaua (si no podían escusarlo) protestando interiormente que lo hazían forzados. Tenían por cierto que cada uno se podía saluar en la ley de Christo, Judío y Moro, guardándola cada uno fielmente: de donde nació convertir tan pocos dellos San Vicente Ferrer'; Marcos de Guadalajara, Memorable expulsión y justísimo destierro de los moriscos de España (Pamplona: Nicolás de Assiayn, 1613) fol. 159r-v.

'que con el permiso y licencia que su maldita Secta concedía, que en ocasiones forçosas pudiesen fingir en lo exterior, y sin pecar, qualquier religión con tal empero que conservasen el coraçon para su falso y embaydor Profeta; vimos morir tantos dellos adorando la Cruz y hablando bien de Nuestra Religión Cathólica siendo en el interior finos Mahometanos'. De Guadalajara, Memorable expulsión; apud Florencio Janer, Condición social de los moriscos de España [Madrid: Imprenta de la RAH, 1857] (Seville: Espuela de Plata, 2006), p. 215. 
punishment and for this reason it is easy for them to request and receive Christian baptism and outwardly confess the faith of Jesus Christ. ${ }^{48}$

Although one could provide further quotations of this sort, this one speaks for the rest. ${ }^{49}$

\section{Is There Islamic Doctrine in Support of the Propositions of which Moriscos were Accused?}

What were the main Islamic principles that may have lay behind the points made by León and virtually all the contemporary polemicists who wrote on this subject throughout the seventeenth century?

One notion which does exist in Islam is that, according to some Muslim theologians, man possesses an innate capacity to know God. That innate capacity, part of human nature, receives the name of fitra in the hadith containing the following words of the Prophet Muhammad: 'each infant is born with a right religious nature (fitra), it is his parents who make him a Christian, a Muslim or a Zoroastrian'. ${ }^{50}$ However, this is one of several contradictory traditions on the ability of the infants of unbelievers to be saved, ${ }^{51}$ and Islamic

$48 \quad$ Parescer de don Martín de Salvatierra, obispo de Segorbe, del Consejo del R.N.S. dado por mandado de su magestad ... acerca del estado en que están los moriscos del reyno de Valencia y de la reformación en instrucción que se trata de darles, 30 July 1587, Biblioteca Nacional de España [BNE], ms. 5785. Document published in Pascual Boronat y Barrachina, Los moriscos españoles y su expulsión [Valencia: Francisco Vives y mora, 1901], (Granada: Universidad de Granada, 1992), vol. 1, pp. 618-19. The italics are mine. To cite further fragments of the text: 'Item, se confirma mas esto y la notable burla y menosprecio que todos ellos hacen de la religión xpiana ... y procuran ser compelidos y apremiados a hacer estas obras christianas con injuria suya porque tienen en doctrina de sus maestros y antepasados que en ello ganan gran mérito delante de mahoma y que pueden exteriormente negar a mahoma reteniéndole en sus corazones ...', p. 622. 'Item, como esta dicho tienen por fee y por doctrina ... que si se les hiciere alguna fuerza o violencia para haverla de negar [su secta], la pueden negar, retiniendola en el coraçon questo les basta para salvarse', p. 623 .

49 See Diego Rubio, 'La taqiyya en las fuentes cristianas: indicios de su presencia entre los moriscos', Al-Qanțara, 34 (2013): pp. 529-46, and its references for a complete view.

Yasien Mohamed, Fitrah: The Islamic Concept of Human Nature (London: Ta-Ha Publishers, 1416/1966); and D.B. MacDonald, 'Fitra', Encyclopaedia of Islam II (1991), pp. 931-32: and Camilla Adang, 'Islam as the Inborn Religion of Mankind: The Concept of Fitra in the Works of Ibn Ḥazm', Al-Qanțara, 21 (2000): pp. 391-410.

Ana Fernández Félix, 'Children on the Frontiers of Islam', in Conversions islamiques. Identités religieuses en Islam méditerranéen (Paris: Maisonneuve et Larose, 2001), pp. 61-71. 
theologians have remained uncertain and in some disagreement over the question of fitra. According to Ibn Rushd, the innate character of man's ability to know God guarantees his salvation with very little effort. For many others, the text evidently meant that every child is born naturally a Muslim, but is perverted after birth by his environment, an interpretation that clashes with the idea of the sovereign will and hidaya (guidance) of Allah. Al-Gazhali, an author who was very widely read in Al-Andalus, seems to have interpreted fitra not as Islam but as a proper 'original nature' that can be altered by environmental circumstances. ${ }^{52}$ It is very striking that Christian polemicists, and perhaps also Hispanic Muslims, followed this interpretation, for example in holding it to be a Muslim teaching that every human being is primordially born a Muslim. In this reading, human nature and man's innate reason lead him to Islam, and he is only swayed from that right nature by the education received from his parents and the place where he happens to have been born. Spanish polemicists certainly knew of this hadith. For example, Joan Martín de Figuerola, in his work of anti-Islamic controversy Lumbre de fe contra la secta mahometana y el alcorán (1521) cites the Qur'ān 4:17 to explain the Mudéjares of Aragon's belief that 'the children of the Jews and the Christians are all born Moors and the Jews make them Jews and the Christians Christians ... all human beings are born within the law of Muhammad. I wonder at you, alfaquí, for God has given laws as it is written ... and if God makes them be born as Moors, how does He also give other laws?'53

As for the alleged Muslim belief that each is saved in his own law, both González Santalla and Sanz seem to have been referring to either Qurān 2:62, 'Surely those who believe and those who are Jews and the Christians and the Sabians, whoever believes in Allah and the Last Day, they shall have their reward from their Lord, and there is no fear for them nor shall they grieve', or Qur'ān 5:69, 'Surely those who believe and those who are Jews and the Sabians and the Christians, whoever believes in Allah and the Last day and does good, they shall have no fear nor shall they grieve'.54

With regard to dissimulation, there is an Islamic concept known in Arabic as taqiyya which expresses the legitimacy of dissimulation in situations of

52 Al-Gazhali, Al-Munqid min al-dalal [Confesiones. El salvador del error. Spanish trans. by Emilio Tornero (Madrid: Alianza Editorial, 1989), p. 30].

'que los ninyos de los judíos y los christianos todos nascen moros y que los judíos los hacen judíos y los cristianos cristianos ... que todos los seres humanos nascen en la ley de Mahoma. Estoy maravillado de ti, alfaquí, que Dios tiene dadas las leyes como está escrito ... y si dios les hace nascer moros, ¿cómo después da otras leyes?'; Lumbre de fe contra el Alcorán, RAH, Gayangos 1922-36, fol. 89v.

The Holy Quran, (trans.) M.H. Shakir (Tehran: A Group of Muslim Bros., 1970). 
violence or compulsion. Christian polemicists seem to have known and made use of this precept of taqiyya or legitimate dissimulation of belief. The term itself is never employed by the polemicists; neither does it ever appear in Morisco texts, not even once. But to Christians, the conviction that such dissimulation took place became a source of anxiety and mistrust, and they were permanently on the alert to its dangers. ${ }^{55}$

The total absence of this term from Morisco texts has led some scholars to think that the Moriscos dissimulated in the same manner as many other dissident or heterodox groups. ${ }^{56}$ Modern historians have long known and written of legitimate dissimulation as a prevalent mind-set in the sixteenth century. It was not exclusive to the new converts nor to the Iberian Peninsula, as can be seen from the contemporary phenomenon of Nicodemism, the doctrine allowing religious dissimulation which was attacked by Calvin and others. ${ }^{57}$ Indeed, there are even some historians, such as Pérez Zagorin, who have characterized this period as a European 'age of dissimulation' which affected not only religious belief but also political attitudes. ${ }^{58}$ It was not a device that was exclusive to ideologically marginal or minority groups or individuals, whose viewpoint was completely closed: it was also deployed among the political and social elites, where simulation and dissimulation became a 'way of life' with positive associations linked to prudence and the manner of governing oneself when obliged to live under the yoke of tyranny. ${ }^{59}$ Nevertheless, it should be high-

55 See the monographic section dedicated to the topic of 'Taqiyya, legal dissimulation', Al-Qanțara, 34 (2013), coordinated by Mercedes García-Arenal.

56 Luis Bernabé Pons, 'Taqiyya, niyya y el Islam de los moriscos', Al-Qanțara, 34 (2013): pp. 491-527. An opposing view is held by Rubio, 'La taqiyya en las fuentes'.

57 'Excuse de Iehan Calvin a messieurs les nicodemites, sur la complaincte qu'ilz font de sa trop grand' rigueur' (1544), in Calvino, Opera quae supersunt omnia, vol. vi (Brunsvig, 1867). Eleonora Belligni, Evangelismo, Riforma ginevrina e nicodemismo. L'esperienza religiosa di Renata di Francia (Cosenza: Brenner, 2008).

58 Pérez Zagorin, Ways of Lying: Dissimulation, Persecution and Conformity in Early Modern Europe (Cambridge: Harvard University Press, 1990). Also Jon R. Snyder, Dissimulation and the Culture of Secrecy in Early Modern Europe (Berkeley: University of California Press, 2012).

59 Rosario Villari, Elogio della dissimulazione. La lotta politica nel Seicento (Rome: Laterza, 1987); Albano Biondi, 'La giustificazione della simulazione nel Cinquecento', in Eresia e Riforma nell'Italia del Cinquecento (Firenze, Chicago: Sansoni, Newberry Library, 1974). More recently: Luca Addante, Eretici e libertini nel Cinquecento italiano (Rome: Laterza, 2010). For Spain, see for example, Fernando R. de la Flor, Pasiones frías. Secreto y disimulación en el Barroco hispano (Madrid: Marcial Pons, 2005). 
lighted that the term taqiyya is frequently used in legal texts from the Al-Andalus period which the Moriscos knew and used. ${ }^{60}$

We can conclude, then, that there did exist an Islamic doctrinal basis for the claims of Christian polemicists concerning a series of attitudes and beliefs they had detected in the Moriscos. However, on re-reading these deeply significant extracts one cannot help feeling that these polemical texts are indulging in a game of mirrors in which orthodox Christians displayed a defensive attitude, not only towards Islam but towards all beliefs deemed deviant and dangerous within the heart of Hispanic Catholicism. An attempt was being made to combat a number of beliefs and attitudes among the Christian flock by resorting to the device of presenting them as embodied in the Muslim adversary. This can be seen even more clearly in the case of pronouncements made concerning the inheritance of belief.

\section{Belief is Inherited. Natura or the Iberia of Blood and Milk}

Endless Inquisition trial records contain examples of the following statement, as uttered by Moriscos: mi padre moro, yo moro (my father was a Muslim, therefore I am a Muslim). The belief that one tends to follow the religion of one's father was, despite the texts alluded to here, not restricted to Muslims. We can also find many instances of it in Inquisition trial processes of Old Christians and Conversos. The notion that an individual followed the faith of his ancestors was widespread and firmly rooted at all levels of society. Belief was part of one's legacy, part of the genes transmitted by one's ancestors, without the need even to have been educated in it. Following this same line of thought, Old Christians often called themselves cristianos de natura and many Conversos confessed that they had 'judaized' because their parents had been Jews. Nación and natura are words derived from the same root which point both to the group of people among whom an individual is born and, at the same time, to the religion into which one is born (judios de nación), which is transmitted by blood or even milk. Mamé la fe católica con la leche, as formulated by Cervantes in the mouth of a character in El Quijote. ${ }^{61}$ It was believed that the naturaleza of the blood that runs through an individual's veins as well as the milk sucked at the breast of one's mother contained his or her beliefs and values. Belief could, according to some, be transmitted by the milk of wet nurses to the suck-

\footnotetext{
60 Devin Stewart, 'Dissimulation in Sunni Islam and Morisco taqiyya', Al-Qanțara, 34 (2013): pp. 439-90.

$61 \quad$ El Quijote, vol. 2, ch. 63.
} 
ling baby, and there was a current of opinion claiming that it should be forbidden for women of Jewish or Muslim origin to nurse Christian babies. ${ }^{62}$

Birth, nation, nature, belief: all these concepts are embodied in the two words, nación and natura. It is sometimes extended to cultural manifestations related to religion such as the use of language. Thus it was that Antonio de Sosa, author of a famous sixteenth-century work about Algiers, wrote of certain renegades and their children that, although born in Algiers, 'at the breast they learned the natural Christian talk of their fathers and mothers and they speak it as well as if they had been born in Spain or Italy'.63

Christian belief in the connection between faith and the corrupting nature of Jews had been commonplace since the fifteenth century. ${ }^{64}$ But less attention has been paid to the fact that this belief also encompassed the Moriscos. Their religion came to be equated with 'nature' in the sense of biological origin, as was made clear by the Inquisitor of Valencia, Pedro de Zárate, on 6 July 1587: 'As these new Christians have their sect from their mother's breast, as by nature, there can be no confidence that out of fear of punishment they will

62 Julio Caro Baroja has gathered very interesting texts in the chapter 'La leche mamada y el fermento' in his book Las formas complejas de la vida religiosa. Religión, sociedady carácter en la España de los siglos XVI y XVII (Madrid: Akal, 1978), 489 and ff. For example, the text by father Juan de Pineda, 'que mujer morisca ni de sangre de judíos criase a hijo de cristianos viejos, porque aun les sabe la sangre a la pega de las creencias de sus antepasados, y sin culpa suya podrían los niños cobrar algún resabio que para después, de hombres les supiese mal'. Also, about Jewish nurses who nurture babies who become judaizing men, Caro Baroja, Los judios en la España moderna y contemporánea (Madrid: Arion, 1961), vol. 2, pp. 306, 409 .

63 'Dejemos aparte que hay muchos turcos y moros que han estado captivos en España, Italia y Francia, y, por otra parte, una multitud infinita de renegados de aquellas y otras provincias y otra gran copia de judíos que han estado acá, que hablan español, italiano y francés muy lindamente, y aun todos los hijos de renegados y renegadas que en la teta deprendieron el hablar natural cristianesco de sus padres y madres, le hablan tan bien como si en España o Italia fueran nacidos'. Antonio de Sosa, text published under the name of Diego de Haedo, Topografía e Historia General de Argel (Madrid: Instituto de Estudios Africanos, 1927-29).

64 As Gavetas da Torre do Tombo (Lisbon: Centro de Estudos Históricos Ultramarinos, 1960), vol. 1, p. 109. Year 1527, 'estos christianos nuevos de Portugal son como un enfermo que tiene una dolencia yncurable y sin embargo desto tienen otro mayor mal que tienen el ayre e baho tan dañado e con tanta ponçoña que dapña e corronpe a qualquier que a el se llega y estoy en punto de dezir que abasta en ponçoñar con la vista solamente a los que de su calidad son, pues luego bien será que con tiempo sea esto remediado antes que mas dañados ayan ... porque este dapnificamiento que cada dia va creciendo a rienda suelta sin parar se puede mui bien ver por esperiencia que los que fueron baptizados pequenos y ansy los que después nacieron son tanto dañados como los viejos'. 
give up their Moorish ceremonies and sect'.65 The Morisco Jesuit Ignacio de las Casas made reference to mother's milk when he complained that the Moriscos took no notice of those like himself who had made sincere conversions and were learned men, instead saying to them things like como tu te as criado con esa leche desde niño, sábete bien (since you have been brought up on that milk since you were a child, it tastes good to you), or si tu ubieras gustado (la leche) de tus antepasados, no dixeras eso (if you had tasted the milk of your ancestors you would not say that). ${ }^{66}$ And it was the argument that it was impossible to abandon one's own nature that was used by a group of Muslims who themselves sought to dissuade one of their own who wanted to convert, Juan de Santa María. ${ }^{67}$

Even more interesting is the famous trial process of an Old Christian from Cuenca, Doctor Eugenio de Torralba. ${ }^{68}$ In Rome, Torralba had met a man of Converso origin named maestro Alfonso, who had confronted him with doubts over which religion to believe in and hesitation over which of them might be best for achieving salvation. ${ }^{69}$ In this particular case of Doctor Torralba, these doubts, which he shared with Alfonso, were resolved thanks to the milk drunk at his mother's breast, which had instilled Christianity in his physical being. When interrogated by the Inquisitors, Torralba confessed his periods of doubt regarding the Catholic faith:

He said he had been in that error for a period of twenty years, sometimes believing it for as long as three years but then returning to faith in Christ and when he said the words that witnesses claimed they had heard him say, he believed and held that Christ was not God and that a teacher called Alfonso who had been in Rome and was first a Jew and then a Moor and then a Christian, talked to this confessor of his crimes and told him that everything in the Old and New Testament was deceit and that Christ did not die, denying that there were any apostles and denying all the other sacraments of the Church, and that he believed in the law of Muhammad and that he persuaded him of this often in his younger days,

65 'Como estos christianos nuevos tienen su secta desde la teta, como por naturaleza, no ay confianza que por temor de la pena dexarán sus ceremonias y secta de moros'.

66 El Alaoui, Jésuites, Morisques, p. 574.

67 Juan de Santa María, Thesoro de cosas raríssimas históricas, sacras y profanas (Brussels: Fernando de Hoeymaker, 1622) BNE, R-36503: 'no vees que todo lo que piensas hazer es falso, qué aguardas que no te vas a tu natural?'

68 Archivo de la Inquisición de Cuenca, Cartas del Consejo, Iv: fols. 214-18.

69 The cases of Jews who change religion several times and finish by not believing in any of them are to be found in Caro Baroja, Los judios, vol. 1, pp. 489, 491-95. 
for this was more than twenty years ago, telling him not to believe in the Old and New Testaments but in the law of Muhammad, but this confessor felt scruples in his heart and was made to leave and wander from the path of truth.

He said those things so many times that he doubted and went stray from the path of truth. Also: 'He said he had been diverted from the faith by the teacher Alfonso and became ambivalent and doubtful whether to be a Jew or Moor for if he decided to do so he would not come to Spain but would rather go to Turkey or Barbary to become a Moor, but since he had drunk Christianity at his mother's breast he had never been completely determined nor had the intention to abandon his true Redeemer'. Although this man had been 'doubtful, confused and perplexed', he had in some sense been saved by the milk drunk at his mother's breast, for example by the belief that he had imbibed Christianity as a biological inheritance, and in effect had been born into it. ${ }^{70}$

\section{Doubts about the Efficacy of Baptism in the Case of Muslims}

The idea that belief was inherited was certainly implicit in the principles underlying the statutes of limpieza de sangre, and in the classification of offences drawn up by the Inquisition to reflect the ethno-religious origin of the accused. In fact, this Inquisitorial recourse to genealogy implied a recognition of failure, firstly in the attempt to impose religious conversion, and secondly when trying to judge an accused prisoner's intimate beliefs, which were beyond all scrutiny. There was no way of being certain of the sincerity of converts or their descendants, no way of reaching their inner conviction - if indeed they had one, especially when dissimulation was known to be sanctioned. In my

$70 \quad$ Apud Julio Caro Baroja, Vidas mágicas e Inquisición (Madrid: Taurus, 1967), vol. 1, p. 249: 'Que un maestro Alfonso que estava en Roma, que antes fue judío y después moro y después christiano, hablando a este confesante le dixo que todas las cosas del testamento biejo y nuevo eran burlería y que Christo no murió y assí negava que no huvo apóstoles y todos los sacramentos de la Iglesia y que creya en la ley de Mahoma y que tantas vezes le persuadió aquesto en sus tiernos años ... que con esto este confesante pasó escrúpulo en el ánimo y le hizo apartar y desbiar del camino de la berdad'; 'como en la leche mamó ser christiano'; 'aunque estuvo dudoso, confuso y perplexo ... nunca enteramente se animó ni tuvo intención de dexar a su verdadero Redentor'. In another declaration, Torralba confesses that he had experienced doubts about the immortality of the soul because of people he met in Italy and went astray from the doctrine of his parents and the 'preceptos de España'; p. 248. 
view, the most outstanding consequence of this belief in religion by nature is not only its relation to limpieza de sangre, but also that doubts concerning the efficacy of the baptism of Muslims were made explicit in the writings of high church officials when they recommended that priests should stop baptizing their children. Indeed, it was proposed and debated at the end of the sixteenth century that the practice of baptizing Morisco children should be abandoned because they would inevitably end up apostatizing. Biological propositions indicted the whole community, including children, who have the infected root within their guts.' ${ }^{11}$ The argument was that the sacrament was insulted when it was known that such children would act like their parents, or would be corrupted by them. One leading proponent of this line of thought was the Archbishop of Valencia Juan de Ribera, one of the architects of the Expulsion of the Moriscos and canonized as recently as 1960 by Pope John XXIII..$^{72}$ In his time as Bishop of Badajoz, Ribera had already made clear his belief in the union between nature and religion in the case of Jews. In 1565 he denounced, in a sermon devoted to the Holy Office in Badajoz, the heretical vice of Judaism as a sin inherent to the race; that was the reason why Jesus had been forced to address his preaching to the Gentiles, ignoring the portion of his flock that it would have been simply impossible to persuade. For Ribera, those people whom the Holy Office had undertaken to repress were incarnated in 'corrupt churchmen and other Illuminist persons. ${ }^{73}$ Thus this model bishop of the Counter-Reformation offered a formula by which the sin of heresy was linked to the traumatic history upon which Spain's unity of religion had been constructed through decrees of mass conversions and the banning of Judaism and Islam.

Later in his life, when Ribera had become Archbishop of Valencia, he wrote in 1582 on the Moriscos of his diocese, claiming that it was better not to baptize their children. He thought that it would cause 'much less harm to let them go

71 Louis Cardaillac, 'Vision simplificatrice des groupes marginaux par le groupe dominant dans l'Espagne des XVI ${ }^{\mathrm{e}}$ et XVII ${ }^{\mathrm{e}}$ siècles', in Les problèmes de l'exclusion en Espagne (XVI ${ }^{e}$ et XVII ${ }^{e}$ siècles), (ed.) Agustín Redondo (Paris: Publications de la Sorbonne, 1993), p. 14.

72 Giovanna Fiume, La cacciata dei moriscos e la beatificazione diJuan de Ribera (Rome: Morcelliana, 2014).

73 San Juan de Ribera, Sermones de los tiempos litúrgicos (Valencia: Corpus Christi, 1987-89), vol. 5, p. 267. It was a paradoxical claim in light of the support that Patriarch Ribera gave to circles that were thought of as Illuminist, both while he was bishop of Badajoz and later as bishop of Valencia. See Francisco Pons, Místicos, beatas y alumbrados. Ribera y la espiritualidad valenciana del siglo XVII (Valencia: Alfons el Magnànim, 1991), pp. 13-48. 
to limbo than to allow the name of God to be blasphemed. ${ }^{74}$ Ribera considered Morisco blood to be abominable and a transmitter of faithlessness; thence his fear of the Moriscos of the Crown of Castile, who were able to go completely unnoticed and mingle with Old Christians. His view seems to have been that the negative ferment of the Moriscos was transmitted via the blood, making it impossible for children to escape it. ${ }^{75}$ Ribera justified his claim with an example from the Bible: on two occasions the sacred text refers that Rehoboam, king of Judah and son of Solomon, had a mother, Naamah, who was an Ammonite, that is to say a Gentile, 'as if by saying that having a Gentile mother and being brought up by her made the son a Gentile. ${ }^{76}$ This might explain his fear that through mixed marriages the malignant Morisco ferment would be spread throughout Spain.

Archbishop Ribera was not the only man to express doubts about the efficacy of baptism for Moriscos: the Dominican fray Luis Bertrán held a similar view from as early as 1579, when he expressed it in a Memorial where he argued in favor of not baptizing Morisco children unless they were in danger of death. It was better, Bertrán argued, that they remain Muslims than become heretics and apostates. ${ }^{77}$ Jaime Bleda was also of this school of thought and was therefore, like Ribera and Bertrán, in favor of the total and final Expulsion of Moriscos from Iberian territory, thereby introducing further confusion into the use of notions of faith, customs and unbelief. ${ }^{78}$ It becomes even easier to

74 'mucho menos daño dexarlos yr al limbo que no dar ocasión para que el nombre de Dios sea blasphemado'.

75 A text from the first papel (1601) corroborates this: 'Criándose un hijo con padres moros y decendiendo dellos, ha de ser moro' (A child brought up by Muslim parents and descending from them is bound to be a Muslim).

761 Kings 14,21; 2 Chronicles 12,13. Francisco Escrivá, Vida del illustrissimo y excellentissimo señor don Iuan de Ribera, patriarca de Antiochia y arçobispo de Valencia (Valencia: Pedro Patricio Mey, 1612), p. 354.

77 Memorial of 30 December 1579 (Zayas, Los moriscos, pp. 464-65); in the summary of Bleda's Defensio fidei in causa neophytorum siue Morischorum Regni Valentiae, totiusq. Hispaniae (Valencia: Juan Crisóstomo Gárriz, 1610).

78 'Que también se colige su infidelidad, heregía y apostasía de otros infinitos indicios ... Que se apartan de la vida común de los fieles y sus costumbres en todo lo que toca a la fe, en tanto grado que si pudiesen caminar andando hazia atrás, lo harían porque los christianos andan azia adelante. No usan de los vasos de los christianos ni de los propios suyos si algún christiano se ha servido dellos. Su perfidia se conoce en su modo de hablar pues dizen de ordinario: nosotros y vosotros'; 'Sus hijuelos pequeños huyen de los christianos porque sus padres con la leche les enseñan este terror'. He does everything 'por tener la misma creencia que sus padres tuvieron'; Zayas, Los moriscos, ch. 13, pp. 431-32. 'No se administre el baptismo a los hijos niños si han de vivir en casa de sus padres, porque ay 
understand Ribera's fears if we examine his reactions to the prospect of coexisting with Anglican Englishmen. His was a fear of infiltration, undoubtedly, but also a fear of relativism, comparativism, and the idea that if comparisons came to be made, Catholics might not look best in the eyes of some. In summary, his was a fear of the existence of doubt. Ribera was one of the first to denounce an aspect to be feared in the improvement of Spain's relations with the English, who were to reap the benefits of tolerance towards Anglican religious services on Spanish territory, as permitted by the peace agreement of 1604. Coexistence with those who had rebelled against the Catholic church and who were flagrant and unpunished in their rebellion, would lead the Spanish to abandon what was, according to Ribera, a deep-rooted and healthy attitude of hatred of heresy and heretics. The Patriarch wrote: 'And it is at least very certain that the general astonishment and revulsion that used to be felt with regard to the heretics has been lost because as they are encountered every day in the street ... and it is seen that many of them are true to their beliefs more than Catholics, and are more agreeable in their manners, people start to grow fond of them, which is highly inconvenient because of the dependence and brotherhood between love and benevolence of the person and belief in his words and teachings. ${ }^{79}$

Not all Spanish thinkers of the time held such views. But even in the more moderate proposals concerning the Moriscos, the idea of blood and inheritance still prevailed. Pedro de Valencia, author of an important Tratado sobre

evidencia moral que serán Apóstatas como ellos, y más vale que sean Moros que hereges o Apóstatas. Es tan intrínsecamente malo dar, fuera del peligro de muerte, el baptismo a estos niños presupuesto todo lo sobredicho, como si un christiano baptizase los niños hijos de los moros que están allende ... Y es averiguada cosa que este christiano pecaría mortalmente, no por hazer injuria a los padres que consienten en ello, sino por la injuria que se hace al sacramento y a la fe ... Por tanto, lo más acertado será suplicar a Su Magestad de proponer este negocio clara y distintamente al Vicario de Jesuchristo (al Papa) para que Su Santidad determine lo que se ha de hazer y el cómo. Y assí se eviten tantas blasphemias contra Nuestro Señor y por consiguiente aplaque su yra y no nos embíe tantos castigos de hambres y esterilidades como en este Reyno padescemos' (Zayas, Los moriscos, p. 465).

79 'Y por lo menos es certísimo que generalmente se ha perdido el asombro y grima que se solía tener de los herejes, porque como los topan cada día por las calles ... y ven que muchos dellos guardan verdad más que los Cathólicos, y son más agradables en el trato, viene la gente a aficionárseles, lo que es grandíssimo inconveniente por la dependencia y hermandad que tiene el amor y benevolencia de la persona con el dar fe a sus palabras y creherles lo que enseña', Carta que escribió ... Juan de Ribera sobre las pazes. sf (1605) Biblioteca Universitaria de Barcelona, ms. 1008-1010, vol. 1, fols. 53-59, quotation on fol. 55r. Apud Olivari, Avisos, pasquines, p. 93. 
los moriscos written in 1606 in the midst of the debate over a possible Morisco Expulsion, ${ }^{80}$ came down against the measure but advocated instead what he called permistion, that is, a deliberate mingling of blood via mixed marriages, in order to bring about the end of the Moriscos and leave only Old Christians remaining. Such a strategy would have to be supported by a lack of discrimination against the children of mixed marriages when it came to awards and benefices. The ultimate aim was to bring about the disappearance of 'that nation and caste [of Moriscos], as a result of their having been mixed up and mingled'. Valencia concluded by pronouncing: 'It would be best, then, not for the Moriscos to be equal in offices and honors to the Old Christians, but for the Moriscos to come to an end and for there to remain only Old Christians in the kingdom; all the republic would be made up of people of one name and purpose, undivided, so that there should be no dissension. ${ }^{81}$ The idea that only Old Christians would remain as a result of the proposed inter-mingling implied that Old Christian blood would dominate the mix and produce the beliefs and mentality required. In the battle of the bloods, the Old Christians would emerge as victors.

The opinions of Juan de Ribera and those who thought like him represent an acknowledgement of total failure with regard to the Moriscos and the grand enterprise of total conversion which had started a century earlier in a messianic, optimistic spirit. But they also convey a lack of belief in the grace bestowed by the sacrament of baptism and reveal skepticism not only in regard to the attainment of truth but also the transmission of the true faith to others. The ethnic aspect of religion certainly implies the existence of racialist or racist notions, but it also implies that of a deep-seated skepticism.

This skepticism was philosophical and epistemological. It is worth remembering that in Spain the work which contributed most decisively to the dissemination of the ideas of Sextus Empiricus was that written by none other than Pedro de Valencia, Academica sive de iudicio erga verum ex ipsis primis fontibus, published in Antwerp by Plantin in $1596 .{ }^{82}$ Pedro de Valencia's work shows that substantial and detailed knowledge of ancient Skepticism (the Skepticism of Cicero in his Academica and of Sextus Empiricus and Pyrrho) was available in late Renaissance Spain and considered relevant to contemporary social and political issues. It could form part of a humanist

$80 \quad$ Pedro de Valencia, Tratado acerca de los moriscos de España, (ed.) J. Gil Sanjuán (Málaga: Almuzara, 1997). See also by Pedro de Valencia, Sobre el Pergamino y Láminas de Granada, (ed.) Grace Magnier (Oxford, Bern: Peter Lang, 2006).

81 Valencia, Tratado acerca, pp. 123-25. See Benítez, Heroicas decisiones, pp. 124-25.

82 Pedro de Valencia, Obras Completas. Vol. III: Academica (León: Universidad de León, 2006). 
intellectual's repertoire of historical and philosophical knowledge. According to Valencia himself, writing towards the end of the sixteenth century, the ideas of Sextus Empiricus were extremely well known in Spain..$^{83}$

\section{Implicit Faith and Natural Law}

In the preceding pages I have analyzed the propositions attributed by seventeenth-century polemicists to the Moriscos and explored the possible roots of these claims in Islamic Sunni doctrine. However, and in spite of anything that may have been written by the polemicists, such notions were not solely Muslim, nor were they proffered only, or even mainly, by Moriscos. For example, the Inquisition persecuted belief in the existence of an 'implicit faith' and the upholding of the idea that such implicit faith together with natural law were enough for men to be redeemed. This fideistic tradition lasted throughout the whole of the sixteenth century and diluted the polemical force of the claim that knowledge and love of God were not only innate in the human heart, but also that the different manifestations of that innate belief in the form of religions were of no more than secondary importance. Fray Luis de Granada (d. 1584) famously argued that love of one's parents and love of God are by nature connected and stamped on the hearts of all men ${ }^{84}$ :

Other reasons were given by the philosophers, and Tullius (Cicero) rightly took much notice of them. One of these was the idea that although there are so many nations in the world and they are so varied, there is not a single one so barbarous nor so savage that, although it does not know which might be the true God, it nevertheless understands that there is One and honors Him through some form of veneration. The cause of this is (apart from the beauty and order of this world, which bear witness to the fact that there is a God governing it) that the Creator Himself, just as He impressed on the hearts of men a natural inclination to love and revere their parents, did also impress upon them another similar inclination to love and revere God as the universal father of all things and as their upholder and ruler (Psalm IV). And from this derives the custom of

83 John C. Laursen, 'Pedro de Valencia and Academic Scepticism in Late Renaissance Spain', in Renaissance Scepticisms, (ed.) Gianni Paganini and José Maia Neto (Dordrecht: Springer Netherlands, 2008), pp. 111-23.

84 Fray Luis de Granada, Introducción del Símbolo de la Fe (Salamanca: Herederos de Matías Gast, 1583), p. 39. 
worship and religion which, though it may be false, can be seen in all the nations of the world. All this is so impressed on human hearts that to defend it some nations fight with others without there being any other reason to fight, as we can see in the case of the Moors and the Christians. Because of each one's belief that their law is the true law and that God is truly honored through it and not the others, they feel obliged to speak out for their God and to wage war on those who do not honor Him as they understand He should be honored: to such an extent is the worship and veneration of God impressed on human hearts. ${ }^{85}$

This is a fideistic position, to the extent that Fray Luis does not see reasons for war between Christians and Muslims since they are all devoted to the love of God imprinted by nature on their hearts. The idea of a natural law common to all men also implicitly assumes man's capacity to be saved by this knowledge of God, independently of the religion professed. This was clearly stated by the Dominican Francisco de la Cruz who went only a little further and because of it was burnt in Lima in 1578 for heresy after having, among other things, proclaimed that native religiosity expressed an implicit faith which might have sufficed for salvation, and therefore having dissociated faith from Christian Catholicism. ${ }^{86}$

85 'Otros motivos tuvieron los filósofos de que Tulio (Cicerón) hace mucho caso y con mucha razón, y uno dellos es que, con ser tantas y tan varias las naciones del mundo, ninguna hay tan bárbara ni tan fiera que, dado que no conozca cual sea el verdadero Dios, no entienda que lo hay y le honre con alguna manera de veneración. La causa desto es porque (demás de la hermosura y orden deste mundo, que está testificando que hay Dios que lo gobierna) el mismo Criador, así como imprimió en los corazones de los hombres una inclinación natural para amar y reverenciar a sus padres, así también imprimió en ellos otra semejante inclinación para amar y reverenciar a Dios como a padre universal de todas las cosas y sustentador y gobernador dellas (Psalmo IV). Y de aquí procede esta manera de culto y religión, aunque falsa, que en todas las naciones del mundo vemos. La cual de tal manera está impresa en los corazones humanos, que por sola defensa della pelean unas naciones con otras, sin haber otra causa de pelear, como lo vemos entre moros y cristianos. Porque creyendo cada uno que su ley es la verdadera y que por ella es Dios verdaderamente honrado y no por las otras, paréceles estar obligados a tomar la voz por su Dios y hacer la guerra a los que no lo honran como ellos entienden que debe ser honrado: tan impreso está en los corazones humanos el culto y la veneración a Dios'.

86 Joan-Pau Rubiés, 'The Concept of Cultural Dialogue and the Jesuit method of Accommodation: between Idolatry and Civilization', Archivium Historicum Societatis Iesu, 74 (2005): pp. 237-8o, esp. p. 246. Vidal Abril Castelló, Francisco de la Cruz. Inquisición. Actas. Anatomía y biopsia del Dios y del derecho Judeo-Cristiano-Musulmán de la conquista de América (Madrid: csic, 1992). 
Towards the end of the century the Hieronymite friar Padre José de Sigüenza was also tried by the Inquisition (1591-92). Among other things, he was accused of supporting the following propositions:

That many barbarians and Gentiles and Turks and Moors, although they have no knowledge of our faith, just by believing and understanding that there was but one God and by living in accordance with natural law, could be saved; and that a Turk or Moor who receive any information about our faith and also that of their sect, in doubt over which of these to follow, could find salvation just by believing that there is one God and by living in accordance with natural law. 87

In his defense Sigüenza tried to qualify his claim, stating that what he had said 'was the express doctrine of St Thomas, who argued that with implicit faith it was possible to justify those who lived in a holy manner in accordance with the commandments of the law of God, which are those of natural law, and God would not fail such people and would illuminate them in the ways that $\mathrm{He}$ knows'. Sigüenza was nonetheless accused of sustaining that 'each is saved in his own law' and that the doubts that might be aroused (and which undoubtedly were aroused in many, as Sigüenza himself implied) by the atmosphere of Iberian religious polemic over whether to belong to one religion or another were not doubts that had to be, or perhaps even could be, solved. Or perhaps he held that no one set of dogmas ever could - or even should - attain complete ascendancy. Human beings could only save themselves by believing that there was one God and by following natural law.

\section{Popular Skepticism?}

Many different historians of the fifteenth century have spoken of 'popular Averroism' in their studies of the Jewish and Jewish Converso communities, and have identified as one of the manifestations of that popular Averroism the statement so frequently seen in Inquisition records to the effect that 'there is nothing more [to life] than being born and dying', 'no hay sino nacer y morir'. ${ }^{8}$ Is it right to speak in this case of 'popular skepticism'? ${ }^{89}$ Were the different

87 Gregorio de Andrés, Proceso inquisitorial del Padre Sigüenza (Madrid: FUE, 1975).

88 Márquez Villanueva, 'Nasçer e morir', in addition to his introduction to Juan Álvarez Gato.

89 Nicholas Griffiths, 'Popular Religious Scepticism and Idiosyncrasy in Post-Tridentine Cuenca', in Faith and Fanaticism: Religious Fervour in Early Modern Spain (Aldershot: Ashgate, 1997), pp. 95-128. 
attitudes and propositions analyzed in this essay related to modern skepticism? Reason cannot prove that one of the religions is the true religion. It does not even help one to become a follower of a faith. Jewish polemicists of the Late Middle Ages affirmed that faith was not acquired via argumentation but by other means, especially inheritance, separating this faith from any kind of demonstration, which at all events had to be subordinated to the former. During the lifetime of Juan Luis Vives (1492-1540) this fideistic position, close to agnosticism, which dissociated the world of faith from that of reason, was very well received in Jewish circles, where it was seen as the best defense against aggressive Christian apologetics. Luis Vives' apology De veritate fidei christianae sought to combat the fideistic, traditionalistic and quasi-agnostic flank he saw in Judaism by advocating the inescapable need to reason one's faith, to furnish it with the appropriate testimony of reason. At the same time Vives frequently stressed the limitations of human knowledge and his skepticism about the possibility of acquiring rational knowledge with certainty. ${ }^{90}$ With this went the observation that the Judeoconversos did not see it necessary to follow the law in order to be saved. ${ }^{91}$

Inquisition records showing this sort of attitude are very common throughout the seventeenth century, and it was not only Judeoconversos or Moriscos who were responsible. Only those who stated that 'each is saved in his own law' have so far been systematically studied in the important work of Stuart Schwartz. Those who expressed doubts concerning various Catholic orthodox dogmas have yet to be analyzed. I would like to consider here the case of Francisco de Marcilla, a twenty-three-year-old Latin student, who in 1609 appeared voluntarily before the Inquisition tribunal of Cuenca. ${ }^{92}$ Marcilla went to turn himself in because his confessor, to whom he had explained his doubts, had told him that he was unable to absolve him and that he had to go to the bishop or the Inquisitors, which the young man duly did, probably not only because his confessor had recommended him to do so, but also because he had expressed many of his propositions and doubts in public and therefore faced the risk of being turned in by others. Francisco had said in conversation with others that Jesus was not God, but just a 'big Jew'.

90 Lorenzo Casini, 'Self-knowledge, Scepticism and the Quest for a New Method: Juan Luis Vives on Cognition and the Impossibility of Perfect Knowledge', in Renaissance Scepticisms: International Archives of the History of Ideas. Vol. 199 (Dordrecht: Springer, 2009), pp. 33-6o.

91 See in particular the commentaries of Pedro de Valencia on the Epistle of St Paul to the Galatians: 'Los flacos en la fe de los convertidos al judaísmo no lo creían para sí necesario el observar la Ley para salvarse'.

92 ADC, Leg. 380, exp. 5393, years 1609-12. 
Francisco had been assailed by doubts for four years, wondering, for instance, whether Jesus Christ was God or whether the miracles attributed to him were true. But above all, and apart from his doubts, he approved of the belief that there is but one God and that it was enough to follow natural law 'without forcing men to believe faithfully the other articles that we have and the evangelical precepts ... he thought that it was enough to believe in one sole God and not to do to others that which one did not want for oneself'. Francisco thought this was best, 'and it made most sense to him because it seemed to him that it was achieved almost by natural demonstration'. He thought, further, that men should live their lives in accordance with 'natural reason', placing in doubt the certainty of faith. He had arrived at these positions by comparing and relativizing, seeing that 'there was such a wide variety of sects' and that the members of these sects all honored God in their own way, just as he honored God within the Catholic faith which he professed. For all these reasons he had reached the conclusion that 'the safest thing was to follow natural law'.

But Francisco was also periodically assailed by doubts about the existence of God. At times he did not know if there was a God or whether 'nature produced us', and at times he thought that 'there was no more than being born and dying like irrational animals; sometimes he thought it might be like this and at others he had his doubts'. And he thought that each found salvation in his religion because he thought it impossible that so many Muslims and so many Lutheran Christians or so many Gentiles should be condemned if it were true, as he found it hard to accept that there was only one true religion. Indeed, there were occasions when he read some of the canons of the Holy Council of Trent in which some heresies were condemned and it seemed to him that the Council was not right and that its opponents, those classified as heretics, might be. He also thought that the Pope and the Church might be wrong in some articles of faith, given that the Pope himself had free will. Francisco had an additional problem with free will and asked himself how it could tally with the omniscience of God, if 'man himself could move himself to do good or evil, whether he can take the liberty to do this or whether God has guided him'.

In Francisco de Marcilla's trial process we find examples of many of the propositions analyzed above, linked to beliefs of a naturalistic kind and other issues raised by the Lutheran reformers. There are also examples of what contemporary literature described as 'atheistic' ideas, as we have seen, and which involved the denial of immortal life. This was clearly enunciated by Pedro Calderón de la Barca in his A Dios por razón de estado in the dialogue between Thought, Wit and Atheism, in which Atheism shows its lack of certainties and its inability to decide whether God exists or not, arguing instead that 'Yo no se que hay / más que nacer y morir. / Y así argumentos dejemos / y porque amigos 
seamos / comamos hoy y bebamos / que mañana moriremos' (I do not know that there is / anything more than being born and dying. / So let us leave off our arguments / and be friends, / let us eat and drink today, / for tomorrow we will die).

\section{Skepticism and Inheritance of Belief}

After analyzing the materials above, I believe it is indeed possible to ask oneself to what extent the debates within the heart of Catholic Christianity, and the attacks on Catholicism from other reformed versions of Christianity, were transferred into an inter-religious Iberian polemic, for example whether the beliefs of dissidents, reformers and Protestants were attributed to the Conversos, and whether a 'heterology' was constructed which encompassed dissidents, heretics, and Moriscos. ${ }^{93}$ One might ask whether the struggle against fideistic ideas which we have just seen had any impact on how polemicists and evangelizers re-interpreted certain principles of Islam. This form of speaking to others really came down to speaking to oneself. This is what the available material seems to indicate, without this proposal being incompatible with the fact that the Moriscos based or thought they based their positions on Islamic principles. It is also impossible not to raise the issue of the connection between these attitudes and currents of skeptical thinking present in Spain since the mid-sixteenth century.

In the part of this paper in which I presented statements made by men like Juan de Ribera on the inevitability of the inheritance of belief, I made a connection between, on the one hand, this way of thinking and a racialist conception of religion, and on the other the limpieza de sangre statutes. But it was also a deeply skeptical position. It was skeptical to believe that one's religion was an accident of birth.

In his well-known essay 'Apologie de Raimond Sebond' (1580), Montaigne enunciates a form of racial and cultural relativism, stating, 'We are Christians in the same way that we are Perigordians or Germans' ${ }^{94}$ This essay was in fact

93 Heterology is 'discourse that is other and of the other' in the words of Michel de Certeau, Heterologies. Discourse of the Other (Minneapolis: University of Minnesota Press, 1986). Mercedes García-Arenal and Felipe Pereda, 'On the Alumbrados: Confessionalism and Religious Dissidence in the Iberian World', in The Early Modern Hispanic World: Transnational and Interdisciplinary Approaches, (ed.) Kimberly Lynn and Erin Rowe (Cambridge: Cambridge University Press, 2015).

94 Michel de Montaigne, Ensayos completos (Madrid: Cátedra, 2013), p. 449. 
a critique on the positions of the Catalan philosopher Raimundo de Sabunde (d. 1436) whose Theologia Naturalis Montaigne had translated into French in 1569. Against Sabunde, Montaigne argued that neither reason nor the natural order can lead man to the knowledge of God. Against the skeptics who claimed that it was impossible to state or deny the truth or falsehood of anything and that there was no difference between right and wrong, the French fideists (like Montaigne, who wrote that true belief is a lucid acceptance of the religious traditions of one's country, and is distinct from conviction) opted for adapting one's behavior to prevailing custom, to what everybody else did..$^{95}$ This is a form of skepticism not far from that of the proponents of each person believing in the religion of his own parents, as the only way of solving the problem of the absence of a criterion for truth, of reacting in the face of doubts regarding man's capacity to know. Religious polemic had been able to demonstrate the falsehood of some 'truths' but had never been able to provide convincing proof of any. Implicit in the idea of 'the inheritance of belief' were many points that skeptics were subsequently to raise: the relativity of opinion, the lack of criteria for certain judgment, the inaccessibility of truth, and the need to separate matters of faith from all other areas of human knowledge. In early modern Spain, as Robbins has shown, skepticism came to be identified with the claim that no certain knowledge was possible in any area of human activity, from intellectual disciplines down to simple acts of perception, this latter point becoming the central focus of discussion and the key moral dilemma for many Spaniards in the seventeenth century. ${ }^{96}$

95 Juan Marichal, 'Montaigne en España', Nueva Revista de Filología Hispánica, 7 (1953): pp. 259-78. 